\title{
製鐵用石炭の灰分について
}

(昭和 24 年 4 月本會譵演大會にて講演)

\section{侾々 木茂 式 \\ STUDIES ON THE ASHES OF COKING COALS, PRODUCER COALS AND OTHER COALS FOR IRON AND STEEL PRODUCTION}

\begin{abstract}
Shigeichi Sasaki
Synopsis: The author has studied on the kinds, chemical compositions and the refractoriness of askes of coking coals, producer coals and other coals. And the relations between ash quantities of coals and fixed carbon, volatile matter, moisture and calorie values of them, and the refractoriness of ash were also investigated.

The total number of samples presented to the test were abont thirty-five, which were mined at various districts in Japan, Saghalien, North-China, Manchuria and Canada. Of these samples, the greater part were those of Japan and Saghalien coals, besides four kinds of North-China coals, two kinds of Manchuria coals and one kind of Canada coal were presented to the test.
\end{abstract}

\section{I. 緒 言}

石炭の炏分はその多少が登熱量の大小左存する成分 として重㟙されてるる他に，從來より又次の諸點に深い

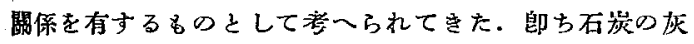
分顿化點如何が焚塏裝置に於ける燃燒效率及びガス發生

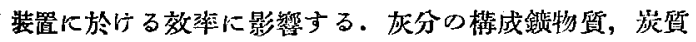
内に於ける分布弲態及び化學成分は龙軟化點の高低さ左. 右する．原料炭の場合，灰分の化學成分如何が裴錨に影

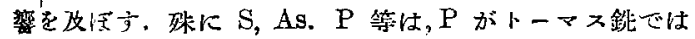
有用成分であるが一般には有害成分となる。裴錩用，应 延用ガスの發生煇用炭の場合には，石炭に含有される $\mathrm{S}$ の含量及び形㦔と同時に灰分の化學組成如何が發生され

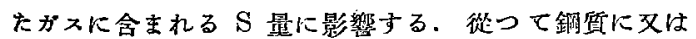

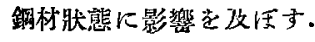

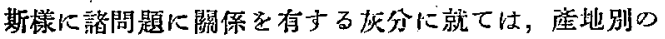
石炭個々に於て灰分が石炭内によ゙の上うに含まれるかを 暊徽筑，X線，或は浮沈分別法その他の方法により研究

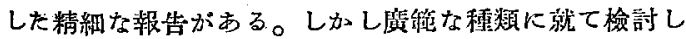
且つ相互に比較した報告の㻐表は割合に抄ない，歐米に 於ては石奖使用の分野によつて灰分の愹蠤點に嫢格を設 けてるるが吾國では座出石炭の特珠性，その他の諸事情 によつて未だそのよらな規格が設けられてるない，原料 炭の場合飞粘結性の可洗装吕裳面の最む重要な性質をな

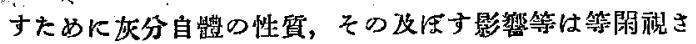

れ燃ちである。

筆者は，それ等の點に留意し裂鐡用原料炭及び一般炭

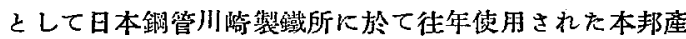

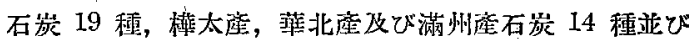
に昨年輸入の米炭 I 種等の灰分と灰分に關聯した諸性質 を檢討調查した。

\section{II. 石炭灰分の種類}

石炭の灰分と棌されるすのは，石炭内に含まれる可燃

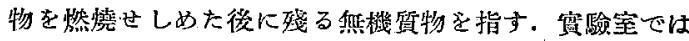
マッフル嘴で 700 $750^{\circ} \mathrm{C}$ に石竝粉粒を加熱して得ら れる。

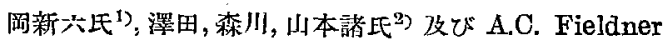
\&W.A. Selvig 氏尚等に從ひ分類せば次ぎの如くなる。

(a) 混入灰分 探炭ら際に混入した上下蟞又はパー チング破片

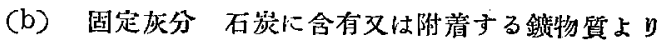
集㶱せるせの。

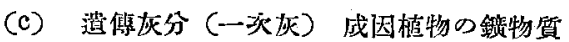

(d) 唂生灰分（一或は二次灰）泥炭時代又之の後 に侵入沈澱したもの.

工業分析上から灰分と程するのは上祀灰分の合計を指

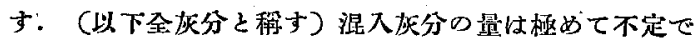

* 日本銅管川崎集鐵所技術研究所 
ある．遗復旅分は同一炭厤の石炭では大體その質及び量 は一定であり一般には炭質內に均等に分巵する。しかし

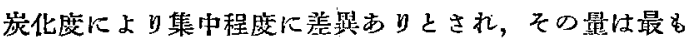
少ないるので約 5〜9\%．以亦をされる．後生灰分の量は

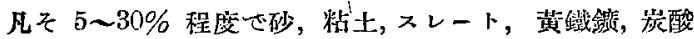

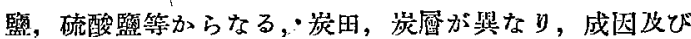

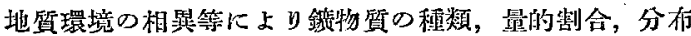
狀態等が逗ふが，米國 Illinois 及び西ペンシルベ $=ア$

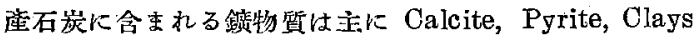
(kaolinite) 改び少量の他の领物類であると言はれる。

\section{III. 浮沈分別試驗結果}

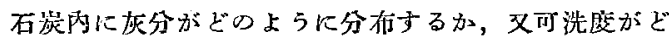
の程度であるかを知るため $\mathrm{BaCl}_{4}$ 等の重比重溶液を利用し石湠を浮游部を沈降部の 2 部分に分別する試驗方法が行はれる。文選炭のために 重比重液選炭法が米國で赛際に场用されてるる。本研究 に於てす約 15 種の石炭に就て比重 1.34 の監化カルシ ウム重比重液を使用し浮沈の2部石炭, その割合，龙分 の分布狀㿦，灰化後の灰分量及び灰軟化點，化學組成の

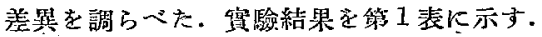

一方沈降部石炭俚約 $31 \cdot 0 \%$ にとどをるが，灰分量住 $23 \cdot 16$ - 52.43\% の高率を示す．浮游部石倣收得集 $65 \%$

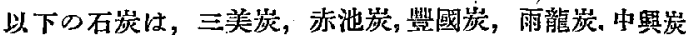
日姫炭，等であり，浮游部石炭の灰分量は $5 \cdot 17$ 11.37\% を示し，全灰分量約 $11 \cdot 87 \sim 26 \cdot 00 \%$ K饈比して低い.

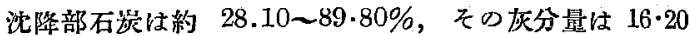
〜35.60\% にして全灰分量に蛙比し高率である。

备種石炭のすへては，大別して軟化點の高低を晎にす る2部分の灰を含有する．浮沈分別による浮游部石炭仡 含まれる微粉末狀灰分の軟化點は，沈降部石孷に含まれ る粗粉爿或は塊狀灰分の軟化點に比てて低いしかし雨

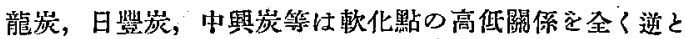
する.本邦湠及び㩰太炭では雨龍炭を除き浮游部石谈の 龙軟化點が $1300^{\circ} \mathrm{C}$ (SK 10) を越凹る.8のはない．

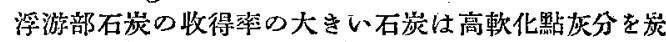

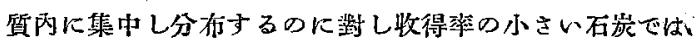
分散し分布せしめる傾向が著しい。

\section{IV. 統計上よりみた各嵝産別石炭 の灰軟化點}

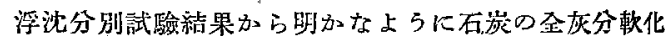

第 1 表 石炭浮沈分別試驗結果

\begin{tabular}{|c|c|c|c|c|c|c|c|c|c|c|c|c|}
\hline & \multicolumn{2}{|c|}{ 浮沈石炭 百分究 } & \multirow{3}{*}{$\begin{array}{c}\text { 平均全 } \\
\text { 灰分百 } \\
\text { 分 率 } \\
\%\end{array}$} & \multirow{3}{*}{$\begin{array}{l}\text { 浮沈分 } \\
\text { 别石荻 } \\
\text { 損失百 } \\
\text { 分受 } \%\end{array}$} & \multicolumn{3}{|c|}{ 浮游部石炭灰分(b) } & \multicolumn{3}{|c|}{ 沈降部石炭灰分 (a) } & \multirow{3}{*}{$\begin{array}{c}\begin{array}{c}\text { 浮游部 } \\
\text { 灰分 }\end{array} \\
\frac{\text { 同上石岸 }}{\times 100}\end{array}$} & \multirow{2}{*}{$\begin{array}{l}\text { 沈降部 } \\
\text { 灰分 }\end{array}$} \\
\hline & \multirow{2}{*}{$\begin{array}{c}\text { 浮游部 } \\
\% \\
\%\end{array}$} & \multirow[b]{2}{*}{$\begin{array}{c}\text { 沈降部 } \\
\%\end{array}$} & & & $\begin{array}{l}\text { 浮游部 } \\
\text { 灰分 }\end{array}$ & 軟 & 七 點 & 洗隆部 & 軟 化 & 點 & & \\
\hline & & & & & $\begin{array}{l}\text { 同上石 } \\
\text { 徒 } \\
\times 100\end{array}$ & ${ }^{\circ} \mathrm{C}$ & ;SK & $\begin{array}{l}\text { 同上在 } \\
\text { 函 } \\
\times 100\end{array}$ & ${ }^{\circ} \mathrm{C}$ & SK & & $\frac{\text { 上同上碳 }}{\times 100}$ \\
\hline 中塊炭 & 8 & $6 \cdot 00$ & 70 & 00 & $3 \cdot 29$ & $116^{\circ}$ & & $55 \cdot 00$ & & $4 a$ & 07 & $3 \cdot 60$ \\
\hline & & 15 & & & $8 \cdot 12$ & $<110$ & $<1 \mathrm{a}$ & $52 \cdot 43$ & & $2 \mathrm{a}$ & .00 & $8 \cdot 60$ \\
\hline 三池粉炭 2 & 0 & $19 \cdot 7$ & & $3 \cdot 40$ & $7 \cdot 79$ & $1.150^{-}$ & $3 a+$ & $5] \cdot 77$ & $1250+$ & $8^{+}$ & 6.00 & $10 \cdot 20$ \\
\hline 大峰選炭 & 6 & 0 & & $0 \cdot 40$ & $9 \cdot 26$ & $1040^{-}$ & $03 \mathrm{a}^{+}$ & $32 \cdot 48$ & 1410 & 14 & $6 \cdot 30$ & $10 \cdot 20$ \\
\hline 管 粉 焒 & & & & $5 \cdot 50$ & $37 \cdot 07$ & 114 & $3 \mathbf{a}$ & $9 \cdot 59$ & $1140^{+}$ & $3 \mathbf{a}^{+}$ & $30 \cdot 40$ & $1 \cdot 20$ \\
\hline 笛韭 笼 & $5 \cdot 00$ & & 26 & $5 \cdot 20$ & $8 \cdot 00$ & 123 & 7 & $28: 50$ & $<1100$ & $<1 \mathrm{a}$ & 0.40 & $25 \cdot 60$ \\
\hline 北小澤粉炭 & $69 \cdot 1$ & & & $3 \cdot 27$ & $5 \cdot 03$ & 112 & $2 \mathbf{a}$ & $28 \cdot 84$ & $1250^{+}$ & $8^{+}$ & & $7 \cdot 82$ \\
\hline 中興粉炭 & & & & $1 \cdot 50$ & $5 \cdot 12$ & 143 & 25 & $16 \cdot 12$ & 1300 & 10 & $2 \cdot 0$ & $9 \cdot 82$ \\
\hline 新幌内中塊岸 & & & $1:$ & $5 \cdot 90$ & $7 \cdot 03$ & 1180 & $5 a^{+}$ & $34 \cdot 78$ & 1320 & 11 & $5 \cdot 75$ & $6 \cdot 39$ \\
\hline " & & & & $2 \cdot 60$ & $7 \cdot 06$ & 108 & $01 \mathrm{a}$ & $39 \cdot 52$ & $1250-$ & $8^{-}$ & & $6 \cdot 77$ \\
\hline 三美中塊咝 & & & 20 & $2 \cdot 23$ & $11 \cdot 29$ & 1180 & $5 a-$ & $32 \cdot 51$ & 1350 & 12. & $5 \cdot$ & $14: 87$ \\
\hline 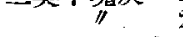 & & & & $6 \cdot 50$ & $7 \cdot 03$ & 125 & 8 & $27 \cdot 04$ & $1610^{+}$ & $27+$ & $4 \cdot 60$ & $7 \cdot 60$ \\
\hline 中塊炭 & & & $21 \cdot$ & $2 \cdot 70$ & $11 \cdot 37$ & 141 & 14 & $34 \cdot 43$ & 1280 & 9 & $5 \cdot 80$ & $15 \cdot 60$ \\
\hline 塊炭 & $50 \cdot($ & $45 \cdot 70$ & $17 \cdot 32$ & $4 \cdot 30$ & $7 \cdot 68$ & 1180 & $5 a^{+}$ & $28 \cdot 12$ & & 20 & $4 \cdot 20$ & $12 \cdot 60$ \\
\hline 塊炭 & & & - & $2 \cdot 56$ & - & 123 & 7 & - & 1580 & 26 & $\ldots$ & - \\
\hline 㴚生中熄炭 & & & & $5 \cdot 36$ & $18 \cdot 40$ & 114 & $3 a$ & $37 \cdot 42$ & $1300^{-}$ & 10 & 12.00 & 11.00 \\
\hline 热顺中塊炭 & & & $13 \cdot$ & $1 \cdot 60$ & $4 \cdot 61$ & 1435 & $15^{+}$ & $35 \cdot 61$ & $1300^{-}$ & $10^{-}$ & $3 \cdot 25$ & $9 \cdot 76$ \\
\hline & & & & $5 \cdot 20$ & $4 \cdot 21$ & 1435 & $15^{+}$ & $39 \cdot 00$ & 1610 & 27 & $3 \cdot 58$ & $5 \cdot 80$ \\
\hline
\end{tabular}

浮游部石炭收得济約 $65 \%$ 以上を示す石炭俚，新况內 炭, 夕張炭，三池炭，彌生炭，北小摆炭，大峰炭，策炭

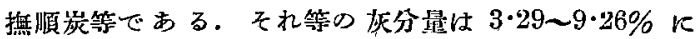
して全灰分量 6.70 18.40\% に比较して極めて低い。
點(以下單に灰軟化點とす)は軟化點の高低を異にする2 部灰分の含有制合の如何火左右される. 同一﨎地同一崖 層の石岸に於てる灰軟化點火或る幅のある筋圍老有する ととななる. 各種石炭の灰顿化點を統計上上りみたのが 
2表である.浮沈分別に上り浮游部石炭の量約 70\% 女上を示寸種類の灰軟化點は統計上集中性を，それ以下 の石炭では分散性の傾向が强い。

本邦炭，檴太炭は華北滿州炭に對比 し軟化點が低い: 米炭一種に比へても低い，代表的發生嘘用炭とされる撨 順炭は全灰分量低く，且つ灰軟化點は $1300^{\circ} \mathrm{C}$ 以上のも のが多いが，本邦及び權太座發生爐用炭には $1300^{\circ} \mathrm{C}$ 以 上の種類が少なく，三美，雨龍，赤池，嚳國等の各炭が $1300^{\circ} \mathrm{C}$ 以上であるのみである。猛逸に於ける用途別に 上る灰分の熔融點梘格に上れば，加熱用炭及ひ發生蠉用 炭では $1300^{\circ} \mathrm{C}(\mathrm{SK} 10)$ 以上，据付汽䌯用炭では $1400^{\circ} \mathrm{C}$ (SK14) 以上，機關用炭では $1500^{\circ} \mathrm{C}$ (SK18) 以上とな ってљる.

上記の如く同一炭にして灰軟化點の高低筑圍を有するこ とは全灰分量の變動に因るがためであるが，第 1 圖に示 广如く全灰分量には石炭個々に個有である幅ある籁图を 有してるた。

\section{V. 座地別の原料炭，發生爐用炭の 灰分化㽚組成及び軟化點}

元來原料炭は粘結性の大なることを要し，能炭用原料

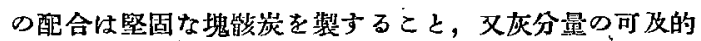
に少ないるのを製するととに主目標加和かれる。從つて 荻分の，化學組成は特別の要求の場合を除をその如何は第 二義的に考一られ勝ちである。 しかし $\mathrm{SiO}_{2}, \mathrm{Fe}_{2} \mathrm{O}_{3}, \mathrm{Al}_{2}$ -

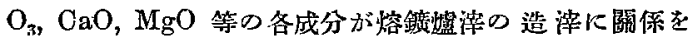
有するのみならず, $\mathrm{P}, \mathrm{s}, \mathrm{As}$, 改び $\mathrm{K}, \mathrm{Na}, \mathrm{Zn}, \mathrm{Ou}$ 等

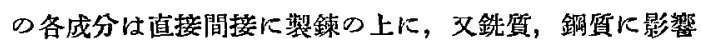
するところ尠なしとしない．原料炭個々に合すれる本來 の鈸物澌，灰分の化學組成を知悉しおくこをは化學冶金 の上からみてる必姴なとと〉责へられる。文灰軟化點は 灰分の化學組成と密势な關聯を有する，上つて内外地産

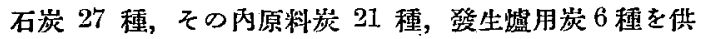
試し化學組成, 浮沙分別に上る浮汇雨部石炭の雨灰分の、 化學組成の相睤及び軟化點を調らべた。供試した石炭類 は特に炭層別にみたるのではなく，且つ種類も少なく限

第 2 表 統計上よりみた各種石炭の灰軟化點分布

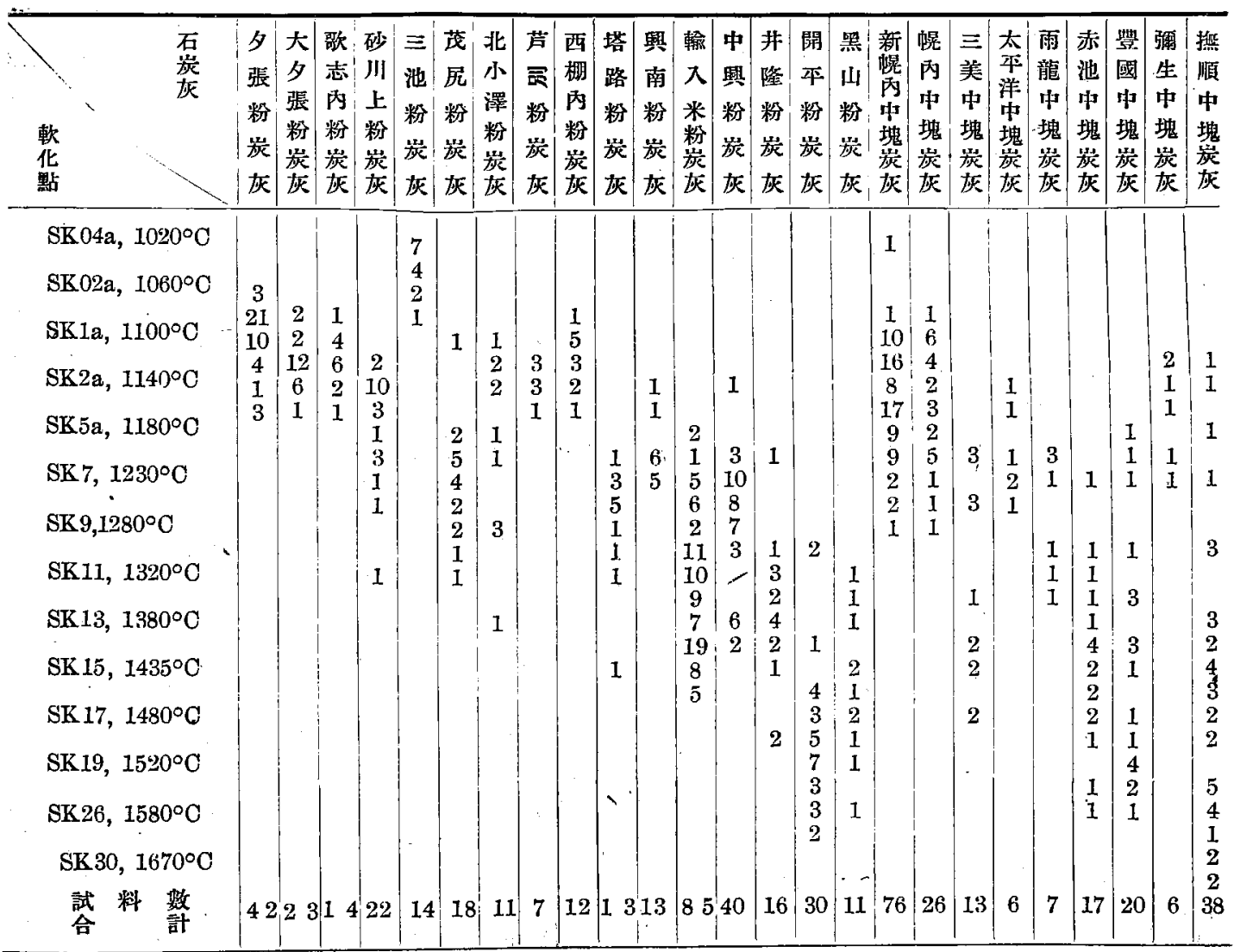




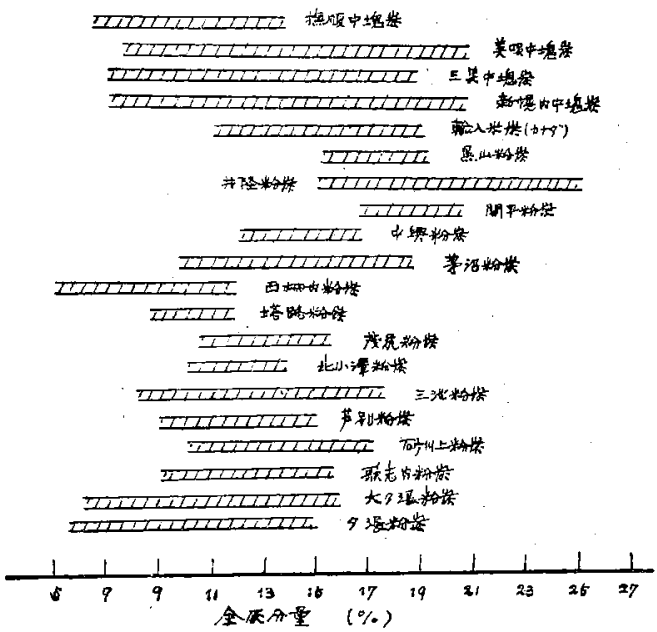

第 1 圖 座地別石炭心灰分量篗園例

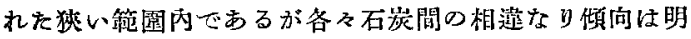
瞭となつた。
ぶて低いのが普通である，しかし前項浮沈分別試驗に於 て例外の性質を示した雨龍炭では逆の關俰にある.中畟 岸の場合も雨龍炭と同裳の傾向を有するものと推定され る.

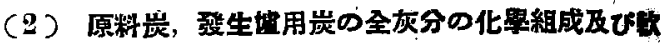
化黙.

全㕱分の化學組成及び軟化點を調らごた結果を第 4 5 装に示す．先つ原料炭では， $\mathrm{Al}_{2} \mathrm{O}_{\mathrm{3}}$ 、は概して本邦炭 に低く $\mathrm{CaO}$ は高い，權太湠は大體本邦炭々同梯の傾向 を有す，大夕張炭，夕脹，歌志內，茂层，西棚内等の各 炭には特に $\mathrm{CaO}$ が著しく高いもの\&みられる. $\mathrm{SHO}_{2}$ は茅梁及び砂川上雨炭が極めて高い他に本邦外地炭々。 に特に著しい美巽をみめられない. Alkali は本邦炭, 恸太炭に高い倾向があり, 殊に夕張, 大夕張, 茅沼, 北 小澤，芦別，西棚內等の各炭には $\mathrm{K}_{2} \mathrm{O}$ の非常に高いの 加ある. S は大夕張, 歌誌內, 茂尻, 三池, 高島, 中興 井陘等の各炭に高く，傾向として本邦及び權太然に割合

籍 3 表 浮沈分別石炭の灰分の化學組成, 軟化點その他

\begin{tabular}{|c|c|c|c|c|c|c|c|c|c|c|c|c|c|}
\hline & \multicolumn{3}{|c|}{ 化 } & \multicolumn{2}{|c|}{ 組 } & \multicolumn{2}{|c|}{ 成 } & \multicolumn{2}{|c|}{ 軟 化 點 } & \multirow{2}{*}{ R } & \multirow{2}{*}{$\frac{\mathrm{SiO}_{2}}{\mathrm{Al}_{2} \mathrm{O}_{3}}$} & \multirow{2}{*}{ 備 } \\
\hline & & $\mathrm{SiO}_{2}$ & $\mathrm{Fe}_{2} \mathrm{O}_{3}$ & $\mathrm{Al}_{2} \mathrm{O}_{3}$ & $\mathrm{CaO}$ & $\mathrm{MgO}$ & Alkali & S & ${ }^{\circ} \mathrm{C}$ & SK & & & \\
\hline \multirow{2}{*}{\multicolumn{2}{|c|}{ 新幌內中瑰炭灰 b }} & $38 \cdot 92$ & $10 \cdot 93$ & $20 \cdot 34$ & $18 \cdot 01$ & $5 \cdot 49$ & $3 \cdot 74$ & $2 \cdot 75$ & 1040 & $03 a$ & $1 \cdot 56$ & $1 \cdot 91$ & 微粉狀灰 \\
\hline & $\mathrm{c}$ & 60.21 & $3 \cdot 04$ & $23 \cdot 63$ & $7 \cdot 30$ & 1.59 & $3 \cdot 50$ & 0.71 & 1160 & $4 a$ & $5 \cdot 43$ & $2 \cdot 54$ & 小塊狀灰 \\
\hline \multirow{2}{*}{\multicolumn{2}{|c|}{ 三美中塊湠灰 $\mathrm{b}$}} & $40 \cdot 84$ & $6 \cdot 78$ & $30 \cdot 49$ & $12 \cdot 43$ & $4 \cdot 19$ & $2 \cdot 59$ & $2 \cdot 66$ & 1300 & 10 & $2 \cdot 81$ & $1 \cdot 23$ & \multirow{2}{*}{$\begin{array}{l}\text { 微粉狀灰 } \\
\text { 小塊狀龙 }\end{array}$} \\
\hline & & $56 \cdot 49$ & $6 \cdot 67$ & $27 \cdot 89$ & $4 \cdot 09$ & $2 \cdot 65$ & $I \cdot 84$ & $0 \cdot 33$ & 1530 & 20 & $7 \cdot 27$ & $2 \cdot 02$ & \\
\hline " & $\mathrm{b}$ & $41 \cdot 70$ & $7 \cdot 68$ & $30 \cdot 50$ & $12 \cdot 25$ & $4 \cdot 73$ & 0.93 & $2 \cdot 14$ & 1250 & 8 & $2 \cdot 81$ & $1 \cdot 36$ & \\
\hline$"$ & c & $57 \cdot 15$ & $3 \cdot 15$ & $34 \cdot 46$ & $2 \cdot 78$ & $1 \cdot 43$ & $2 \cdot 27$ & $0 \cdot 34$ & 1610 & 27 & $9 \cdot 51$ & $1 \cdot 65$ & \\
\hline \multirow{2}{*}{ 雨龍中塊淡灰， } & $\mathrm{b}$ & $59 \cdot 81$ & $5 \cdot 37$ & $28 \cdot 23$ & $2 \cdot 05$ & $1 \cdot 75$ & $2 \cdot 11$ & 0.34 & 1410 & 14 & $7 \cdot 82$ & $2 \cdot 11$ & 粉末狀灰 \\
\hline & c & $58 \cdot 81$ & $9 \cdot 68$ & $21 \cdot 75$ & $3 \cdot 82$ & $2 \cdot 04$ & $3 \cdot 61$ & $0 \cdot 2$ & 1280 & 9 & $4 \cdot 20$ & $2 \cdot 70$ & 小塊狀庆 \\
\hline \multirow{2}{*}{\multicolumn{2}{|c|}{ 珘順中塊炭灰， }} & $48 \cdot 27$ & $8 \cdot 57$ & $34 \cdot 31$ & $4 \cdot 96$ & $1 \cdot 07$ & $0 \cdot 88$ & $1 \cdot 91$ & 1460 & 16 & $4 \cdot 75$ & $1 \cdot 40$ & \multirow{2}{*}{$\begin{array}{l}\text { 微粉狀灰 } \\
\text { 小塊狀灰 }\end{array}$} \\
\hline & & $52 \cdot 98$ & $6 \cdot 31$ & $34 \cdot 26$ & $4 \cdot 05$ & $0 \cdot 39$ & $1 \cdot 28$ & $0 \cdot 75$ & 1650 & 29 & $6 \cdot 91$ & $1 \cdot 54$ & \\
\hline \multirow{2}{*}{$\begin{array}{c}\text { 開平粉炭灰, } \\
\text { " }\end{array}$} & $\mathrm{b}$ & $46 \cdot 84$ & $6 \cdot 18$ & $37 \cdot 27$ & $3 \cdot 39$ & $0 \cdot 92$ & $0 \cdot 39$ & $0 \cdot 60$ & 1250 & 12 & $7 \cdot 73$ & $1 \cdot 25$ & \multirow[t]{2}{*}{$i$} \\
\hline & c & $51 \cdot 88$ & $5 \cdot 70$ & $35 \cdot 28$ & $2 \cdot 45$ & $0 \cdot 80$ & $0 \cdot 33$ & 0.55 & 1630 & 28 & $9 \cdot 39$ & $1 \cdot 47$ & \\
\hline
\end{tabular}

(表註) $\mathrm{b}=$ =浮源石炭部灰分, $\mathrm{c}=$ 沈降石炭部灰分.

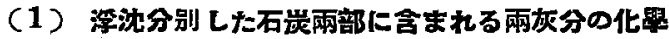
組成と軟化㸃

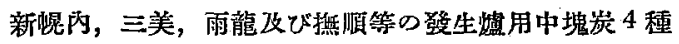
開平粉炭の原料紫 1 種等を重比重液により浮沈分別した 石炭雨部に含まれる雨灰分化學組成及び軟化點を检し，

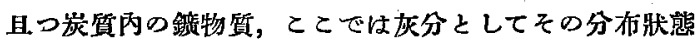
を檢索した。結果を第 3 表に示す。

同一地重の石炭に於て, 浮游部石炭の灰分化學組成は 沈降部石炭の灰分に 對比 $\mathrm{L} \tau \mathrm{CaO}, \mathrm{MgO}, \mathrm{Fe}_{2} \mathrm{O}_{3}, \mathrm{~S}$, $\mathrm{Al}_{2} \mathrm{O}_{3}$ 等の含量が一般に高 $\}, \mathrm{SiO}_{2}$ 量は低い. $\mathrm{S}, \mathrm{CaO}$ は珠に浮游部石炭に著しく宮く含まれてるる。新熀內， 三美の雨炭の場合に特にその閶保が明瞭にみとめ得る. 又灰軟化點は浮游部石炭の灰分の方が沈降部のそれに比
に高い種類が多いよ5である．P は歌志內，神威，北小 潈, 芦別, 塔路、興南, 開平等の备㞸に高い: $\mathrm{Ou}, \mathrm{Zn}$, Mn 等については未判定であるが; As はすべての石炭 に痕跡程度の含量がみとめられる，又粘土類などに極德 基含まれ且つ廣く分布する元素であるバナデンは大抵の 石炭に痕跡加微量含まれてるる。

發生用炭類の場合，原料炭の場合と大略同樣の傾向を 示す. 三美炭を除き本邦炭灰分の $\mathrm{Ai}_{2} \mathrm{O}_{3}$ は抂順炭に比 較して低く， $\mathrm{CaO}$ は著しく本邦炭に高く殊に新幌內に は $22 \%$ といふ高合量を示するのがある. Alkali, 殊に $\mathrm{K}_{2} \mathrm{O}$ は㨨順炭に比でて高く新䖧內文び天浦雨炭の如き は简杽を示す。

軟化點は本邦及び檴太兩炭の場合に㴖華炭及び米炭に 
比゚て低い傾向が大きい，

能 4 表 各種原粼炭の灰化學組成と灰軟化點

\begin{tabular}{|c|c|c|c|c|c|c|c|c|c|c|c|c|}
\hline 石炭鋯柄 & $\mathrm{SiO}_{2}$ & $\mathrm{Fe}_{2} \mathrm{O}_{3}$ & $\mathrm{Al}_{2} \mathrm{O}_{3}$ & $\mathrm{CaO}$ & $\mathrm{Mg} \cdot \mathrm{O}$ & $\mathrm{K}_{2} \mathrm{O}$ & $\mathrm{Na}_{2} \mathrm{O}$ & $\mathbf{P}$ & $\mathrm{S}$ & As & $\begin{array}{c}\text { 軟化點 } \\
\text { SK }\end{array}$ & 備 考 \\
\hline 夕張粉楸 & $54 \cdot 47$ & 5.50 & $29 \cdot 44$ & $3 \cdot 32$ & $2 \cdot 27$ & $0 \cdot 98$ & $2 \cdot 53$ & $0 \cdot 56$ & $0 \cdot 40$ & $\operatorname{tr}$ & $3 a^{-}$ & \\
\hline " & $51 \cdot 41$ & $5 \cdot 10$ & $2 I \cdot 62$ & $8 \cdot 82$ & $2 \cdot 44$ & $4 \cdot 13$ & $3 \cdot 58$ & $0 \cdot 22$ & $0 \cdot 76$ & tr & $2 a$ & \\
\hline 大夕張粉炭 & $43 \cdot 09$ & $8 \cdot 08$ & $20 \cdot 59$ & $14 \cdot 44$ & $5 \cdot 64$ & $0 \cdot 31$ & $5 \cdot 08$ & $0 \cdot 23$ & 2.00 & tr & $2 a$ & 洗 \\
\hline$\pi$ & $49 \cdot 92$ & $5 \cdot 02$ & $25 \cdot 07$ & $7 \cdot 25$ & $3 \cdot 14$ & $4 \cdot 61$ & $3 \cdot 09$ & $0 \cdot 50$ & $0 \cdot 50$ & $\operatorname{tr}$ & $2 a$ & 別口 \\
\hline & $49 \cdot 44$ & $7 \cdot 81$ & $22 \cdot 35$ & $7 \cdot 74$ & $3 \cdot 28$ & $0 \cdot 29$ & $7 \cdot 37$ & $0 \cdot 74$ & $1 \cdot 03$ & tr & la & 洗 \\
\hline 砋川上粉炭 & $\begin{array}{l}50 \cdot 59 \\
70.39\end{array}$ & $6 \cdot 75$ & $29 \cdot 69$ & $6 \cdot 59$ & $2 \cdot 52$ & $1: 20$ & $2 \cdot 68$ & $0 \cdot 84$ & $1 \cdot 22$ & tr & $6 a$ & \\
\hline 吸上粉灰 & $\begin{array}{l}72 \cdot 39 \\
48 \cdot 75\end{array}$ & $6 \cdot 75$ & $19 \cdot 36$ & $\begin{array}{l}0 \cdot 34 \\
7.77\end{array}$ & $\begin{array}{l}0 \cdot 89 \\
2.09\end{array}$ & $\overline{0.09}$ & 0.09 & $0 \cdot 2 \mathrm{~L}$ & - & tr & $\frac{11}{7}$ & \\
\hline . 06 & $52 \cdot 08$ & 5.55 & $26 \cdot 74$ & $6 \cdot 15$ & $2 \cdot 40$ & $\begin{array}{l}3 \cdot 22 \\
0.23\end{array}$ & $\begin{array}{l}2 \cdot 92 \\
1 \cdot 19\end{array}$ & $1 \cdot 02$ & $1 \cdot 30$ & $\begin{array}{l}\operatorname{tr} \\
\operatorname{tr}\end{array}$ & $5 a$ & \\
\hline 神威粉炭 & $51 \cdot 96$ & $6 \cdot 17$ & $25 \cdot 64$ & $5 \cdot 04$ & $1 \cdot 85$ & $3 \cdot 11$ & $3 \cdot 35$ & $0 \cdot 6 \mathrm{~L}$ & $0 \cdot 90$ & $\operatorname{tr}$ & 7 & \\
\hline 茅沼粉炭 & $65 \cdot 46$ & $6 \cdot 40$ & 17.46 & 0.56 & 0.88 & $4 \cdot 98$ & $4 \cdot 23$ & $0 \cdot 18$ & 0.07 & $\operatorname{tr}$ & 9 & 特 \\
\hline & $71 \cdot 32$ & $6 \cdot 11$ & $16 \cdot 64$ & $0 \cdot 37$ & $0 \cdot 64$ & $2 \cdot 11$ & $2 \cdot 39$ & $0 \cdot 18$ & 0.07 & $\operatorname{tr}$ & $5 a^{+}$ & \\
\hline & $71 \cdot 92$ & $5 \cdot 56$ & $19 \cdot 9 n^{3}$ & $0 \cdot 29$ & $7 \cdot 46$ & 0.21 & 0.63 & 0.02 & $0 \cdot 02$ & $\operatorname{tr}$ & $8^{+}$ & \\
\hline 中舆粉炭 & $50 \cdot 62$ & $9 \cdot 43$ & $27 \cdot 56$ & $3 \cdot 58$ & $1 \cdot 09$ & $1 \cdot 78$ & $3 \cdot 09$ & $I \cdot 67$ & $1 \cdot 07$ & $\operatorname{tr}$ & $13^{-}$ & 切込 \\
\hline 3 & $43 \cdot 80$ & $9 \cdot 53$ & $30 \cdot 50$ & $5 \cdot 85$ & $2 \cdot 22$ & $0 \cdot 58$ & $2 \cdot 23$ & $0 \cdot 15$ & $1 \cdot 1.1$ & tr & $6 \mathrm{a}^{+}$ & 17 \\
\hline 井险粉炭 & $49 \cdot 24$ & $8 \cdot 66$ & 29.41 & 4.05 & $1 \cdot 68$ & 0.53 & $3 \cdot 77$ & $0 \cdot 11$ & 0.59 & $\mathrm{tr}$ & 8 & 切込 \\
\hline " & $48 \cdot 50$ & $6 \cdot 41$ & $31 \cdot 42$ & $6 \cdot 09$ & $\perp \cdot 56$ & 1.53 & $2 \cdot 37$ & $0 \cdot 10$ & $0 \cdot 61$ & tr & 14 & $\|$ \\
\hline 開平粉淡 & $54 \cdot 50$ & $6 \cdot 35$ & $28 \cdot 68$ & $2 \cdot 14$ & $1 \cdot 66$ & $2 \cdot 18$ & $2 \cdot 36$ & $I \cdot 87$ & $0 \cdot 30$ & $\operatorname{tr}$ & 20 & 特 \\
\hline " & $48 \cdot 64$ & 5.56 & $37 \cdot 77$ & $3 \cdot 18$ & $1 \cdot 27$ & 0.59 & $1 \cdot 36$ & $0 \cdot 91$ & $0 \cdot 24$ & tr & 16 & $\pi$ \\
\hline 山 炭 & $53 \cdot 22$ & 6.95 & $22 \cdot 69$ & $0.5 I$ & $3 \cdot 19$ & $0 \cdot 74$ & $3 \cdot 19$ & $1 \cdot 81$ & $0 \cdot 10$ & tr & 18 & 切込 \\
\hline 仙 東 炭 & 41.25 & $21 \cdot 75$ & $26 \cdot 09$ & $4 \cdot 35$ & $0 \cdot 97$ & $1 \cdot 64$ & $2 \cdot 02$ & $0 \cdot 12$ & $1 \cdot 51$ & $\operatorname{tr}$ & $12^{+}$ & \\
\hline 北小摆粉炭 & $60 \cdot 42$ & $5 \cdot 96$ & $26 \cdot 30$ & $0 \cdot 18$ & $1 \cdot 40$ & $2 \cdot 24$ & $1 \cdot 98$ & $0 \cdot 82$ & - & tr & $11-^{\circ}$ & \\
\hline 芦別粉炭 & $53 \cdot 76$ & $6 \cdot 75$ & 28.46 & $4 \cdot 55$ & $1 \cdot 30$ & $1 \cdot 78$ & 1.49 & $1 \cdot 94$ & $0 \cdot 76$ & - & $3 a^{-}$ & 特 \\
\hline 西梱內粉炭 & $45 \cdot 22$ & $9 \cdot 43$ & $27 \cdot 07$ & $7 \cdot 65$ & $3 \cdot 80$ & $3 \cdot 92$ & $2 \cdot 46$ & $0 \cdot 37$, & $0 \cdot 70$ & - & $1 a^{-}$ & 切込 \\
\hline 塔 路 炭 & $56 \cdot 32$ & $6 \cdot 95$ & $29 \cdot 06$ & $2 \cdot 06$ & $1 \cdot 66$ & $0 \cdot 69$ & $1 \cdot 43$ & 0.63 & 0.73 & tr & 8 & \\
\hline 興 南 炭 & $28 \cdot 40$ & $4 \cdot 79$ & $24 \cdot 14$ & $2 \cdot 33$ & $2 \cdot 47$ & $1 \cdot 29$ & $2 \cdot 52$ & $0 \cdot 7 I$ & $0 \cdot 16$ & tr & $4 a$ & \\
\hline 名 好 炭 & $64 \cdot 84$ & $4 \cdot 90$ & $29 \cdot 39$ & $2 \cdot 58$ & $1 \cdot 45$ & $3 \cdot 50$ & $2 \cdot 15$ & $0 \cdot 45$ & $0 \cdot 06$ & tr & $9^{+}$ & \\
\hline 鐱 入米流 & $57 \cdot 76$ & 4.09 & $29 \cdot 67$ & $2 \cdot 87$ & $I \cdot 20$ & - & - & $0 \cdot 35$ & $0 \cdot 60$ & & 15 & \\
\hline 7 & $55 \cdot 69$ & $1 \cdot 64$ & $27 \cdot 24$ & $4 \cdot 83$ & $1 \cdot 88$ & - & - & $0 \cdot 96$ & $1 \cdot 23$ & & 16 & \\
\hline II & $57 \cdot 50$ & $5 \cdot 89$ & $31 \cdot 26$ & 1.55 & 0.98 & - & - & $0 \cdot 20$ & 0.20 & & $13^{+}$ & \\
\hline$\not$ & $56 \cdot 70$ & $5 \cdot 00$ & $22 \cdot 81$ & $8 \cdot 42$ & $2 \cdot 30$ & - & - & $0 \cdot 29$ & 0.59 & & 10 & \\
\hline 7 & $60 \cdot 64$ & $3 \cdot 22$ & $27 \cdot 11$ & $4 \cdot 05$ & $2 \cdot 17$ & - & - & $0 \cdot 08$ & 0.24 & & 17 & \\
\hline 高島粉炭 & $46 \cdot 71$ & $7 \cdot 14$ & $26 \cdot 08$ & $9 \cdot 89$ & $2 \cdot 69$ & - & - & 0.385 & $\check{I} \cdot 99$ & & $4 a$ & 月平均值 \\
\hline " & $42 \cdot 31$ & $7 \cdot 45$ & $25 \cdot 35$ & 11.95 & 2.73 & $\therefore$ & 一 & 0.456 & $2 \cdot 82$ & & $3 \mathbf{a}$ & " \\
\hline 三池粉楸 & $42 \cdot 74$ & $10 \cdot 77$ & $14 \cdot 58$ & $15 \cdot 59$ & $2 \cdot 26$ & - & - & $0 \cdot 093$ & $2 \cdot 64$ & & $1 a^{-}$ & 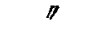 \\
\hline & $43 \cdot 25$ & $9 \cdot 98$ & $18 \cdot 25$ & 15.03 & 2.43 & - & - & $0 \cdot 230$ & $3 \cdot 66$ & & $1 a^{-}$ & 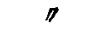 \\
\hline
\end{tabular}

第 5 表 各種發生嘴用炭の灰化學組成と灰軟化點

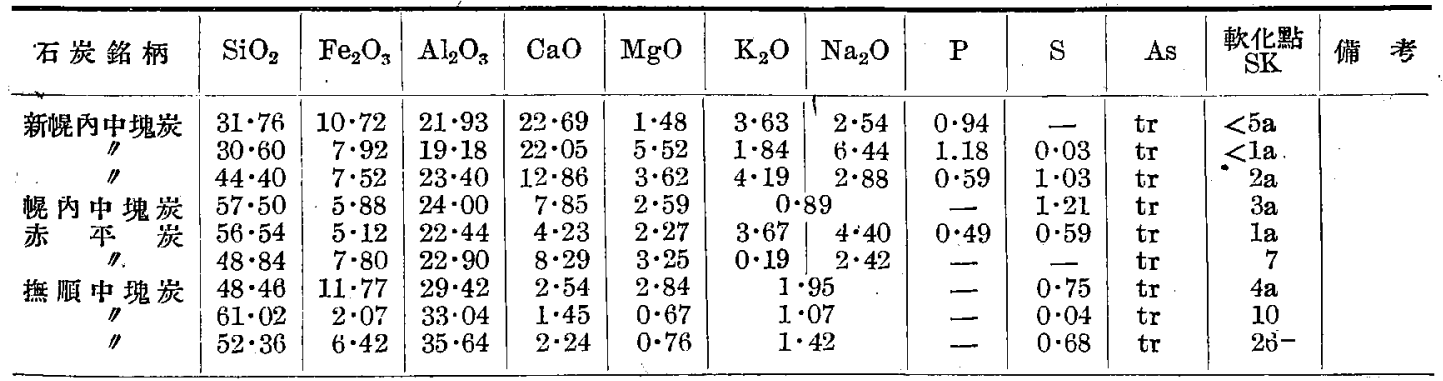

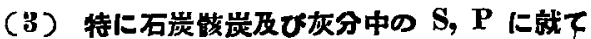

石炭內に含まれる $S$ の化合形態, 分布狀態は虐地種 類により相裂するるのであるが, 一般に Pyritic-S, Organic-S, Sulphate-S の如く分別され考一られてる 3.3)45) Pyritic-S は Pyrite 或は Marcasite として 含まれるものて，その石炭內分布は石炭の種類により著
しく罢なり，石倠を單に破碎することにより文洗炭によ り容易に除去できるすのと然らざる狀䈍で介在するる. Pyrite は炕床父は發生煴內で FeS となり Clinker t 生成しゃしい一因となり易いと言はれ，その含量の高い 石炭は猚迎されない. Sulphate-S の大部分は Pyrites の風化により生じためので炭層風化罡に多いる言はれ 
る. 又 Ca-Sulphate, Gypsum 等は非風化帶の炭層 Joints, Cleavages 等に多く介在し，Pyritic-S と反對 に發热量を低下せしめる因をなる。Organic-SはPyー

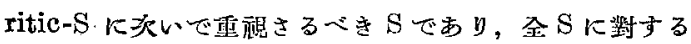
割合は石炭の種類により相造するが大略石炭中の余 $\mathrm{S}$

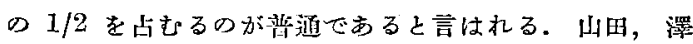
由雨氏5據れば, Pyritic-S 化合物は $400^{\circ} \mathrm{C}$ で分解し $\mathrm{SO}_{2}$ を發生 L, Sulphate-S 化合物は550〜 $600^{\circ} \mathrm{C}$ で分 解し， 又 Organic-S は $600 \sim 800^{\circ} \mathrm{C}$ て分船を始めるる 報じてるる。

J.Hiles \& J.K.Thompson 雨氏6) 並びに Armstro-

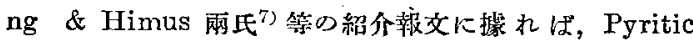
或は Organic-S のいづれであつても石若中に含まれる Sの約 1/2 は战炭に殘留し，それは高溫成で Organic$\mathrm{S}$ の. S が炭素へ固溶する又战炭表面に $\mathrm{S}$ が吸着される がためであると說明されてるると記逃してるる。㕛それ

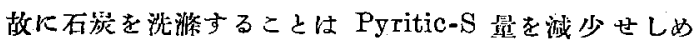
るが低硫黄の㗙炭を裴するには充分でない，褐炭及び源 清楸を $700 \sim 1100^{\circ} \mathrm{C}$ で能荻化する場合に酸化條件では $\mathrm{S}$ の放出吕 $700^{\circ} \mathrm{C}$. 以上でやみ，水素及び空素氣流中で は S 除去が高いことを記してるる。

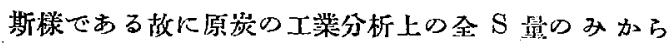

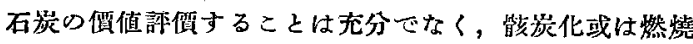

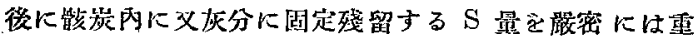
视する必要がある.N.N. Chatterjee 氏4)は特にこの點 から印度 Assam Khasi Hills に於ける Eocene, Tertiary-age の座地別の三種粘結性石炭類について，敬炭 化及び然獟の際の S D化狀態を棓紐に檢討し，殘留 $\mathrm{S}$ 量の大小冶金用原炭の㑑值詐價の一尺度であらねば ならぬこをを指摘してるる。

筆者は同漛の觀點から，石炭及び能曻の炏分に含まれ る $\mathbf{S}$ 量について，特に他成分との關係に於て㒛查した。 結果を䇖 2〜3四に示す。

各地產石炭類を通じ无路炭には， $\mathrm{CaO}$ 量に正比例し て灰分中 S'量が高まる倾向のあることを見出した。 $\mathrm{CaO}$ 分の高い石㞸及び能炭活ど固定すると考一られる

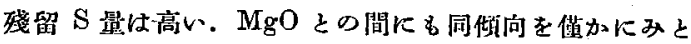
め得るが $\mathrm{CaO}$ 䲞の大小が支配的である。 その他成分々 の間には何等同じ關係をみとめ得ない. N.N.Chatterjee

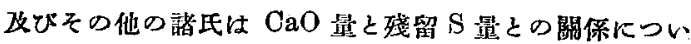
て特に言及してるないが，本䊅果から石炭に含まれる $\mathrm{CaO}$ 量咕，原炭队 $\mathrm{S}$ の化合形態の如何に拘はらず殘留 S 量を左右する最大因子であると制殿できる.

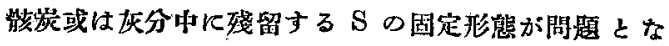

るが， $\mathrm{CaSO}_{4}, \mathrm{CaS}$ 又はその他化合物のいつれであるか 明白でないが $\mathrm{CaO}$ と主に化合し固定するものであると 推定される．特䅀用途の要求から石㞸ブリケット冈内 を固定 (Fixation) する方法について研聟された山田； 摆村雨氏5 に幏れば, $\mathrm{BaO}$ 文び $\mathrm{CaO}$ は石炭に添加し $\mathrm{S}$ を固定するためには $900 \sim 1000^{\circ} \mathrm{C}$ 以下では效果があ る，これは $\mathrm{CaSO}_{4}$ 或は $\mathrm{BaSO}_{4}$ を形成するがためであ るとの推定を報じてるる．この點からぬ Oa-Sulphate として圆定化が起こるるのと推考される。

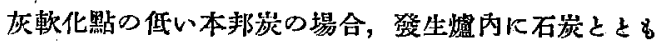
に $\mathrm{CaCO}_{3}, \mathrm{Ca}(\mathrm{OH})_{3}$ 或は $\mathrm{CaO}$ を投入し㜔の軟化點 を高めると同時に S の固定化を計る方法も考いられる

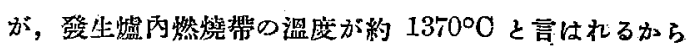

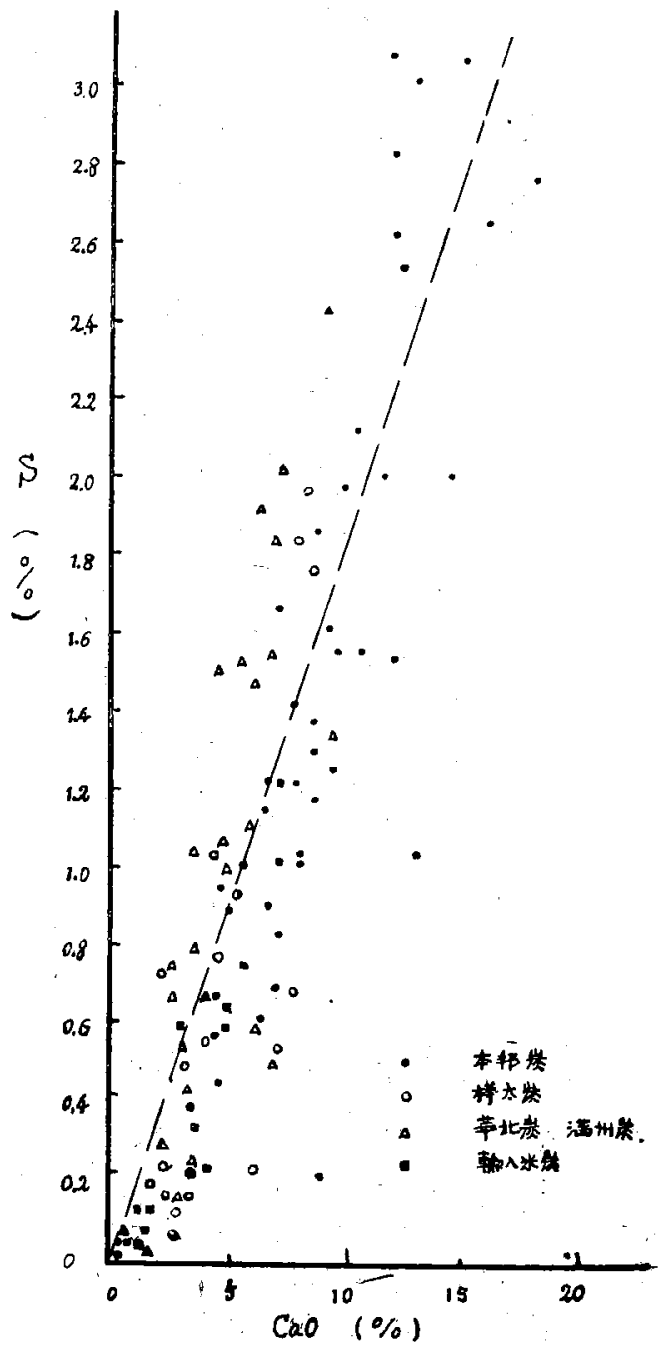

第2 圆、石炭灰分中の $\mathrm{S}$ と $\mathrm{OaO}$ との關保 


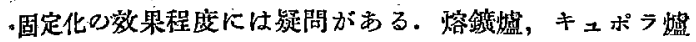
等に锁炭が装入さる」場合，固定した S がどの上らな

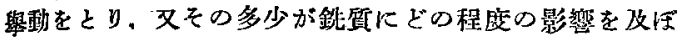
するのかについては今後檢討を裂する。

第 6 表に，各程石炭單味及び配合炭を敬炭化した際の灰 粗成中の $\mathrm{CaO}$ そ $\mathrm{S}$ との關保例として工業分析とともに 和まで表示した。

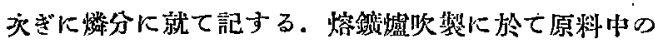
Pの 90\% 以上は鈗に移行すると言はれ，トーマス錐用

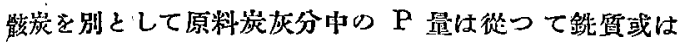

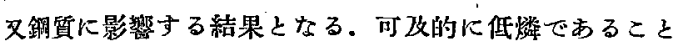

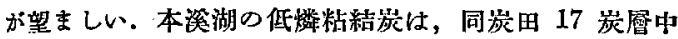

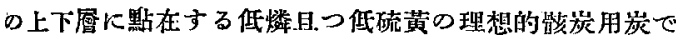

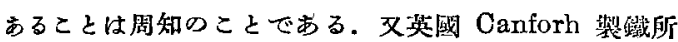

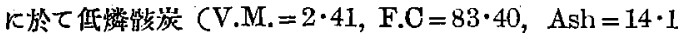
$9, \mathrm{~S}=0 \cdot 40, \mathrm{P}=0 \cdot 010, \mathrm{Cal}=6872 ）$ の主原料 とされると 言仕れる同國 Durham 粘結炭は極めて低燐である之言 はれる. 又嵌炭用石炭として有名な米國の Connelsvi一 le 炭田の最下㕌の石䈐は本均 $0.0094 \% \mathrm{P}$ (その低燐能 炭は $\mathrm{P}$ 平均 $0.010 \%$ ) 之䓂はれる。

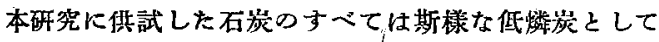
の種類ではないが上記の見地から特に檢討してみた。

$\mathrm{P}$ は歌志內, 神威, 北小澤, 芦別, 塔路, 興南, 中興 開平等の各炭に高に，䩗蕉炭及び輸入米炭には低いもの が多い：Pは炭質內で燐酸アルミナ又は燐酸石灰とし

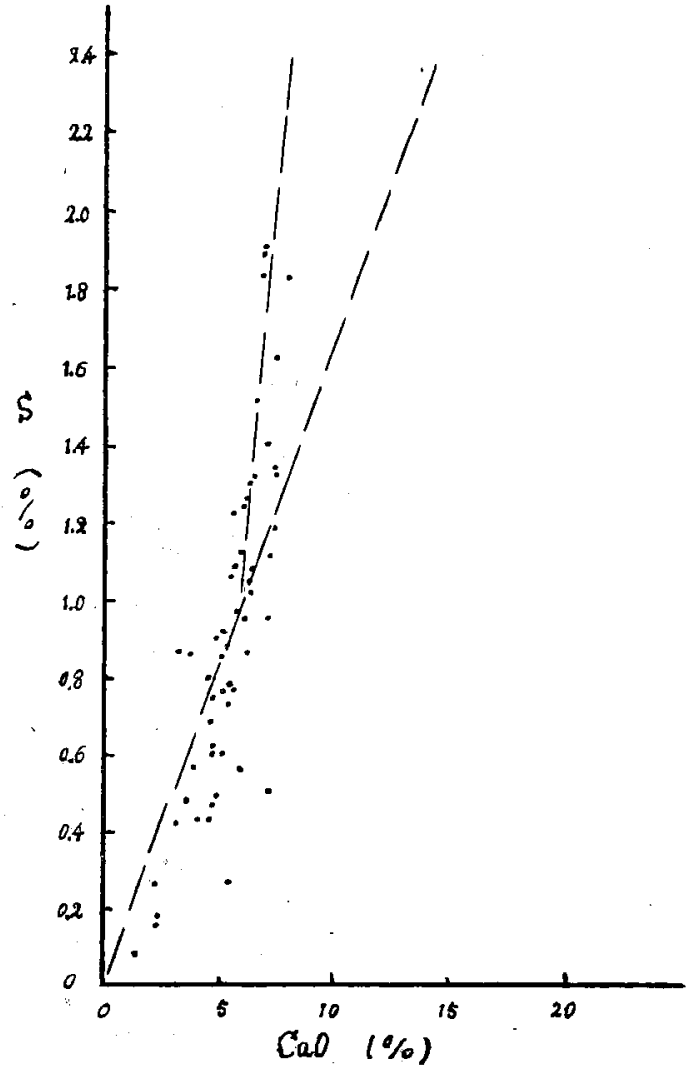

第 3 圆 敂炭の灰分中の S ¿ $\mathrm{CaO}$ との關保

第 6 表 各種石炭單味灭び配合炭を频炭化した際の灰組成中 $\mathrm{CaO}$ と $\mathrm{S}$ と關係例

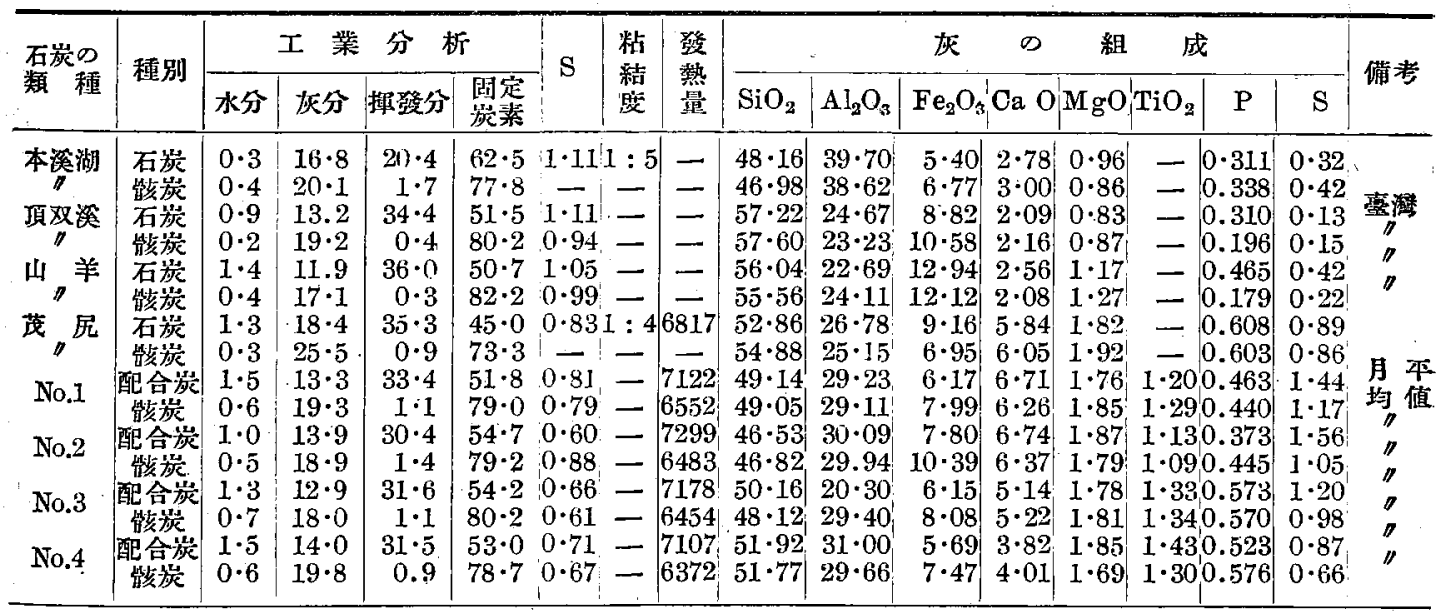

て含まれるるのと一般に考一られてるる. $\mathrm{Al}_{2} \mathrm{O}_{3}$ との間 Кは特定關保をみとめない. 又 $\mathrm{CaO}$ 量との間にも第 4 圆に示す如く $\mathrm{CaO}$ と $\mathrm{S}$ との場合ほどの明確な正比例
關㛊をみとめ得ないが微かに $\mathrm{CaO}$ 量篔加に件ひ高まる 傾向を示す。

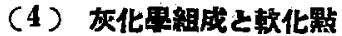




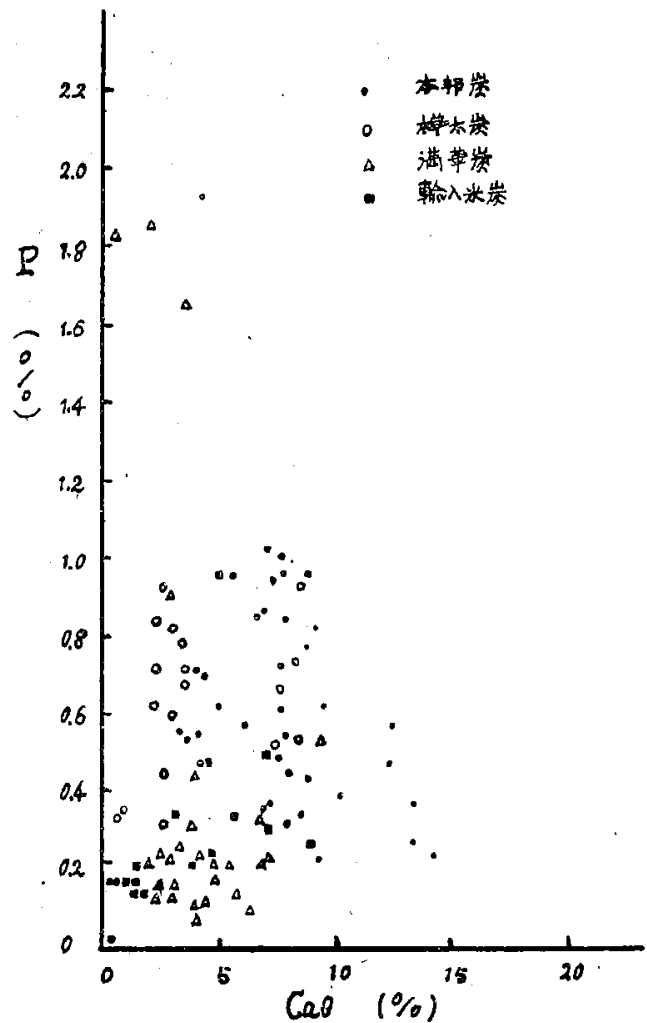

第 4 圖 各種石炭の灰分中の $\mathrm{P}$ と $\mathrm{CaO}$ との關係

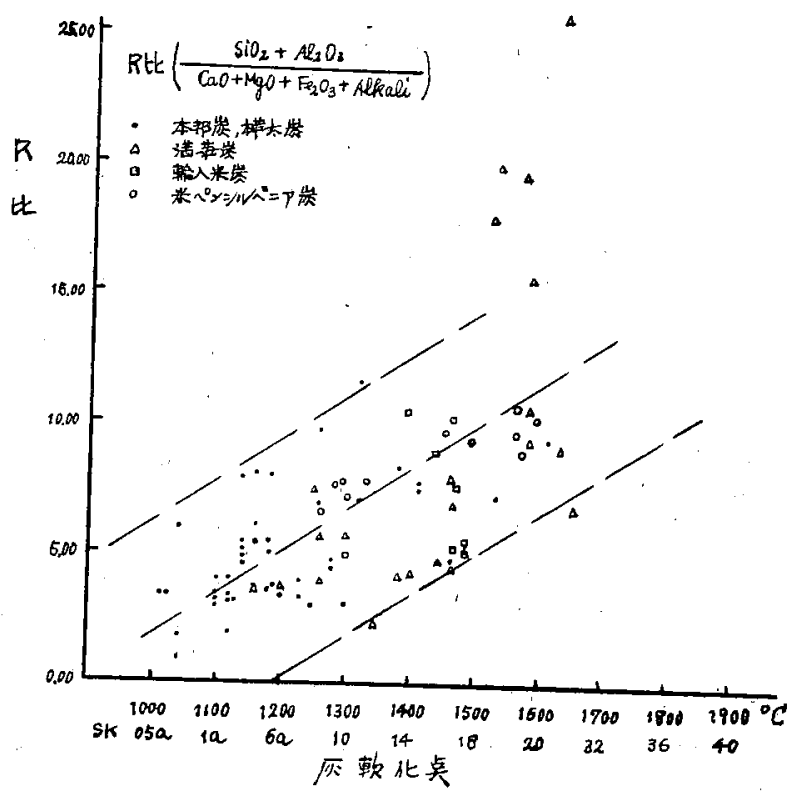

第 5 圆 $\mathrm{R}$ 比と軟化點との關係
灰の軟化點は，炭質內に分布する鋌物質の種類，含有割 合に，灰の化學組成に關聯を有し，その如何によつて后 低を示すことを前記した。耐火度測定の三解雓法(小型)

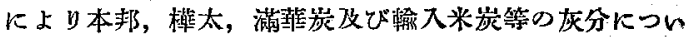

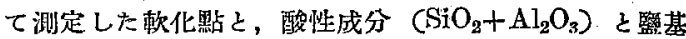
性成分 $\left(\mathrm{CaO}+\mathrm{MgO}+\mathrm{Fe}_{2} \mathrm{O}_{3}+\mathrm{Alkali}\right)$ との比 (R) z の間の關係を求めた結果を第 5 圖に示す。なほ同圆に當 所测定值の他に者までに Oscar-Palmenberg 雨氏日” がペンシルバニア嵌について測定した結果を記入した。

第 5 圆から識らる」よらに，一般傾向として本邦炭改

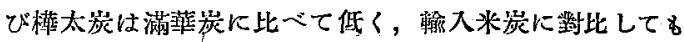
低いるのが多いことが㑇る：R比る軟化點との關㮇は R比の大きい兏い軟化點は高い倾向莨明かに示すが或る 幅を有す. R 此から或る近似值を求得るが絕䝪值は赛 测による他ない，同一地应右炭の場合には略任直線的な 幅の狄い關係がある．R比 15.0 以上の $\Delta$ 印三點は撚㮌 炭の倠であり，同茨の灰軟化點の最高は SK 29 程度で すべての同渗灰の値はその以內にある..

\section{VI. 灰分量己石炭諸性賈との關係}

全灰分は大別して軟化點，化學組成を異にする2 部の 灰分を包含し，同一産地石崁に於ても雨部灰分の割合及 び全灰分量には炭噟或は探炭個所の相遣により大なり小 なりの變動が存すること，全灰分量には夫る個有の籁園 を示すとと前逃した。

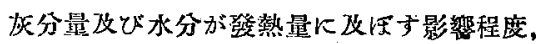
それ等三者間の關係，文純炭發熟量等について 從枆上り檢討され明かるされてるる點が多い。 例二ば，新井孝氏9は多数の本邦座涹青炭並び に褐灰の發熱量に就て研㠰され，燃料比 4 以下 水分 $6 \%$ 以內の石炭類に適用して「ボンブ熱 量計の赛测值に近い發熱量を求め得る計算式, $\mathrm{Q}=88-2 \mathrm{M}^{\prime} \cdot[100-(\mathrm{A}+\mathrm{M})], \quad \mathbf{M}^{r}=(\mathrm{M} / 100-$ A) $\times 100, A=A s h, M=$ Moisture, t提示 $\ell$ た.

篗者は工業分析上の灰分最，發熱量，固定炭 素, 揮發分，水分等，'又次軟化點の諸性算が，各 種の銘柄石燚個々の場合に斯樣な灰分の變化程 度にどの上5敉图で影響さるるものであるか 考惯際に使用する上加ら必要と考一灰分量之諸 性質との關倸, 各種石炭相互の差罢を检索し

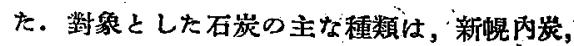
歌志丙炭，茂尻炭，芦別炭，茅沼炭，砂川上炭 等の北海道産，北小澤炭，塔路炭の權太產，開 
平岸，中興炭，井陘炭等の華北產及び翰入米嵌等であ 3.

方法としては多くの場合に湘定値が一直線にのらず分 散するために，同一在地石炭の數多くの試料について圖 示した灰分量龂諸性而の關倸圖から平均直線を求め，個 々石炭のそ机等平均㨁線を同一圆に圆示するととなし た. 郎ち第 6〜9 圖の結果となつた.

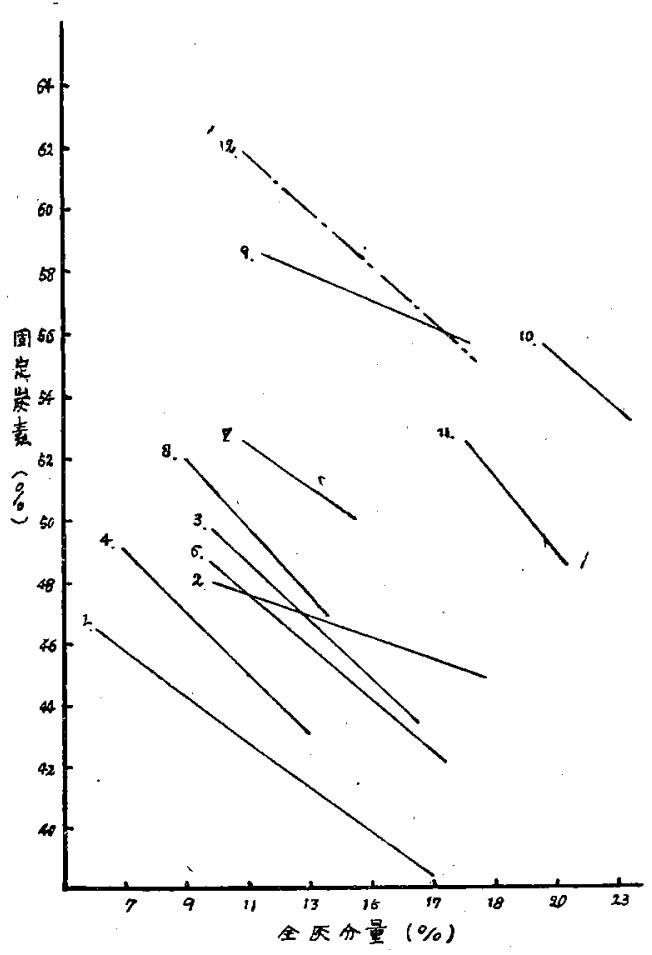

第6 圆 灰分量と囷定炭素との關你

灰分量と固定炭素との關侻は，すへての石㶸に於て反 比例する。各種石浆間では高度瀝青炭に屬する本邦産炭 は固定炭素低く揮發分が高い。權太産 2 種がそれ等に次

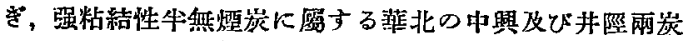

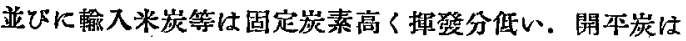
灰分量が著しく高いために固定炭素は割合に低い，雨蹎 線群の角度は 1,2 例外を除き大體同等である。

灰分量と發髙量との關保は，灰分量增加に反比例し登

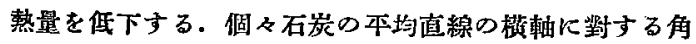
度は概略同等であ する. その點から發欮量は，固定炭素，揮發分，水分等 に影響さるなとと輕微にして灰分量の大小に支配さる」 るのたるととが明膫である.水分と灰分量との間には多 くの種類で特定關你なく分散が甚だしかつた．灰分量と

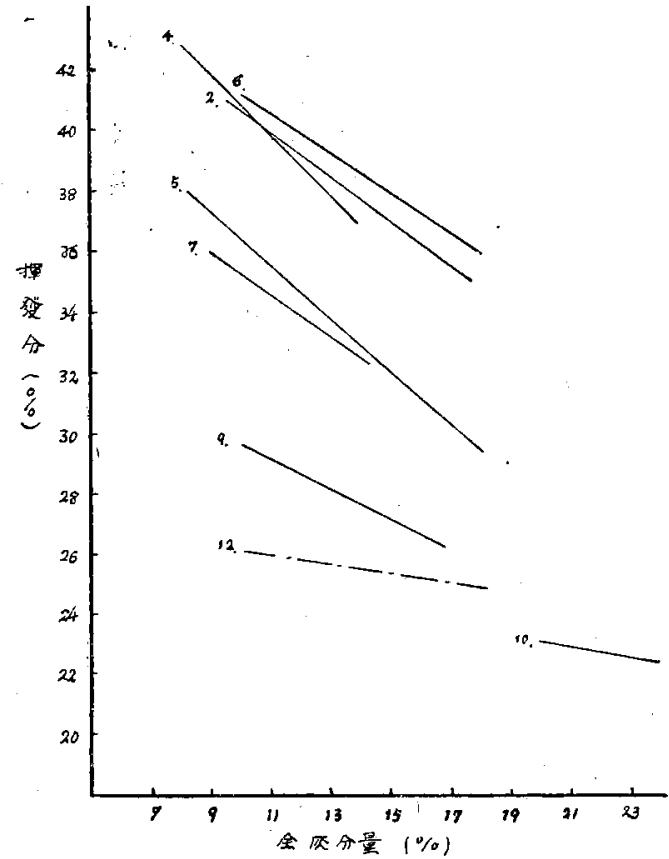

第 7 圆 灰分荲と揮發分との關俰

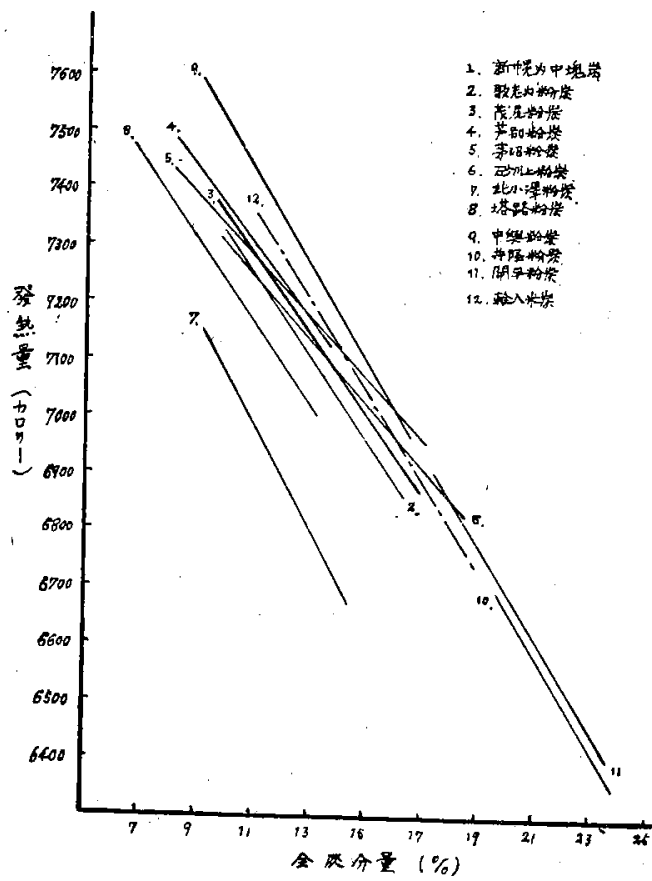

第 8 圆 灰分量と發熱量之の閶保

灰軟化點との關保は，灰分量增加とと软化點の高ま

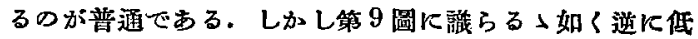
くなる傾向の石炭がある. 輸入米炭, 中興炭及び北小澤 
炭の場合が逆關係にあり，乙の上5な石炭では浮沱分別 による浮游部石炭灰分の軟化點が流降部石荻灰分に比び て高い性啠を有してるる. 又三美炭の如く全く特定關保 なく著しく分散する種類るみられる. これ等は品質. 炭 層の特質又特罢性によるるのと将一られる。

\section{VII. 結䨐}

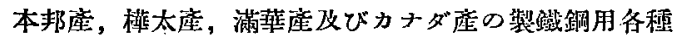

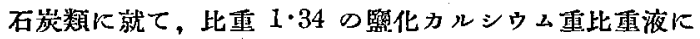
上る浮沈分別法に上り炭質內に於ける在分分布狀態，灰 分の種類，灰分旺，灰分の化學組成並びに灰乾化點を明 かとし，又分別を行はざる石炭の全灰分の同上性質を檢

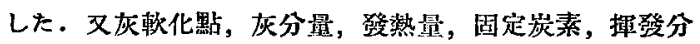
水分等の諧性質の間の關係を調らぶ明瞭とした。

本報告は日本鋼管研究所長菊池浩介並びに前所長藤原 唯義兩氏の御愁篤なる御指導により成つたもので. 趐に 滿腔の謝意を表する.'及化學分析を据當した常所化學研 究課の諸氏に對し深く感謝の意を表する。

(昭和 2410 月笴稿)

$$
\text { 交部 }
$$

1) 岡新六氏; 石炭.

2）濢田，棵川，山本氏; 燃協誌，昭和 16 年, 20 [22S], 811,

3) A.C. Fieidner \& W.A. Selvig 氏; Fuel in Science \& Practice, Vol, XVIII, No2, 56

4) N.N. Chatterjee氏; Fuel in Science \& Practice, 1940 Vol. XII, Jan-Dec.

5)山田，澤村氏; Fuel in Science \& Practice，
I989, Vol, XVIII, 119.

6) J. Hiles \& J.K.Thompson; Fuel in Science \& Practice, 1939, Vol.X VIII, No.8, 225.

7) Armstrong \& Himus; Chemistry \& Industry, 1939, 10. 543.

8) Oscar \& Palmenberg; Ind. Eng. Chem., $1939,31[8], 1058$.

9) 新井慗氏; 突協誌，昭和 14 年，Vol. 559, 343

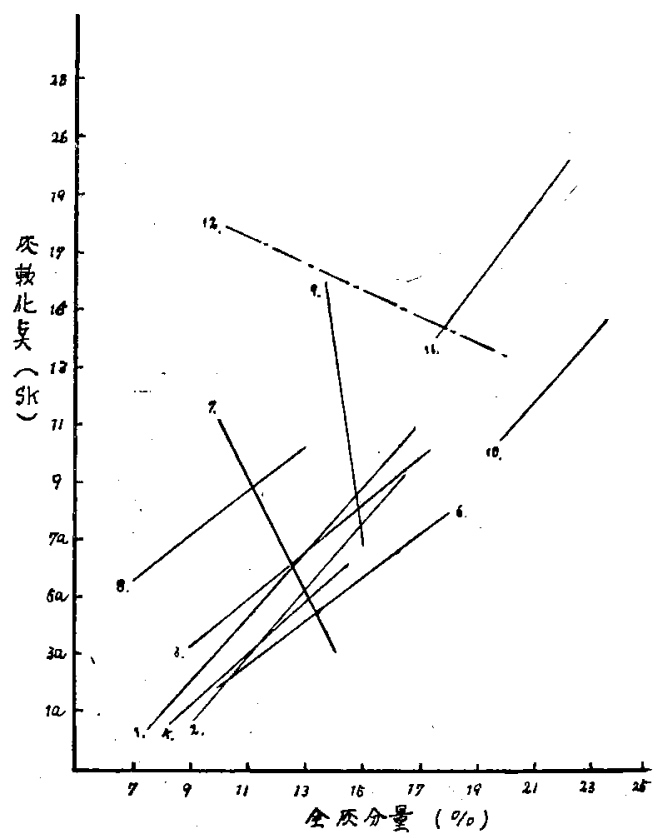

第 9 圆 灰分量と灰軟化點との關保

\section{製鋼用ノツズル・ストツパー煉瓦について}

(昭和 24 年 4 月本會䛨演大會にて篮演)

\section{錦 織 清 治* •丹狗庄 本*}

ON THE NOZZLE AND STOPPER FOR STEEL MAKING

\section{Seiji Nishigori \& Shohei Niwa}

Synopsis : We compared the superiority of the three different types of stopper and nozzle of the same quality after using them in practice and found the proper values of porosity, refractoriness and load softening point among various safety range conditions of them.

\section{* 新大同製銅株式會社}

